\title{
Influences on life aspirations among adolescents in a low-income community in Cape Town, South Africa
}

Gaironeesa Hendricks, Shazly Savahl, Kulthum Mathews, Claudia Raats, Labeeqah Jaffer, Arnold Matzdorff, Bianca Dekel, Christelle Larke, Tapiwa Magodyo, Megan van Gesselleen \& Athena Pedro

To cite this article: Gaironeesa Hendricks, Shazly Savahl, Kulthum Mathews, Claudia Raats, Labeeqah Jaffer, Arnold Matzdorff, Bianca Dekel, Christelle Larke, Tapiwa Magodyo, Megan van Gesselleen \& Athena Pedro (2015) Influences on life aspirations among adolescents in a lowincome community in Cape Town, South Africa, Journal of Psychology in Africa, 25:4, 320-326, DOI: $10.1080 / 14330237.2015 .1078089$

To link to this article: https://doi.org/10.1080/14330237.2015.1078089

央 Published online: 19 Aug 2015.

Џll Article views: 357

View Crossmark data ¿
Submit your article to this journal $\sqsubset$

Q View related articles $\square$

Citing articles: 1 View citing articles 지 


\title{
Influences on life aspirations among adolescents in a low-income community in Cape Town, South Africa
}

\author{
Gaironeesa Hendricks*, Shazly Savahl, Kulthum Mathews, Claudia Raats, Labeeqah Jaffer, Arnold Matzdorff, Bianca \\ Dekel, Christelle Larke, Tapiwa Magodyo, Megan van Gesselleen, \& Athena Pedro
}

Department of Psychology, University of the Western Cape, Bellville, South Africa

*Corresponding author email: gaironeesahendricks@gmail.com

\begin{abstract}
The aim of this study was to determine the influences on adolescents' aspirations from a low-income community in Cape Town. A sequential mixed method exploratory design was used following two distinct phases. The qualitative phase comprised focus group interviews with 118 grade 12 learners attending a school in a low-income community (age range: 16-19 years) and focused on identifying factors influencing life aspirations. The quantitative phase with 191 adolescents $($ males $=54.45 \%$, females $=45.55 \%)$; age range: $14-18$ years $)$ from the same community aimed to ascertain the influences of personal attributes on self-aspirations. Participants completed the Expectations/Aspirations measure, the New General Self-Efficacy Scale, the Rosenberg Self-Esteem Scale and the Multidimensional Scale of Perceived Social Support. Qualitative data were thematically analysed. Quantitative data were analysed using multiple regression. The findings revealed that self-efficacy, self-esteem and social support were the most critical factors influencing adolescents' aspirations. Self-efficacy was a major determinant of life aspirations among the adolescents. Life skills programmes with youth from disadvantaged communities should seek to incorporate training aimed at developing adolescents' self-efficacy.
\end{abstract}

Keywords: Aspirations, adolescents, low-income community, sequential exploratory design, thematic analysis, multiple regression

\section{Introduction}

Adolescents' aspirations play a critical role in the overall development of their psychological well-being (Ryan \& Desi, 2000). Key to understanding the role that aspirations play in the lives of adolescents is identifying the factors that influence aspirations and unpacking the nature and extent of the influences. The over-arching aim of this exploratory study was to provide evidence of these factors from the perspectives of adolescents and to elaborate on the extent of their influence in a low-income community. Life aspirations are evident in various domains: goal-orientation, educational objectives, work ethic and values (Kersteter, 2004).

Super (1980) proposed nine changing roles throughout life, including the role of a child, student, leisurite, citizen, worker, spouse, homemaker, parent and pensioner (Super, 1980). Gottfredson (2005) proposed similar processes in the developmental phase of adolescence from the age of 14 years and older. She described two critical processes in the development of aspirations among young people: circumscription and compromise. Circumscription refers to the process by which adolescents limit their aspirations to what is acceptable, while compromise refers to replacing ideal aspirations with more realistic expectations. Despite Gottfredson's (1981) emphasis on the various roles in a career, Sewell, Haller, and Ohlendorf (1970) argued that it becomes imperative for adolescents to distinguish between educational and occupational aspirations. While educational aspirations reflect educational goals individuals set for themselves (Bandura, 1993), vocational aspirations specifically refer to the process by which individuals set work goals (Hellenga, Aber, \& Rhodes, 2002).

\section{Influences of context}

Adolescents in their aspirations are influenced by factors specific to the individual and to their context such as locus of control (Flowers, Milner, \& Moore, 2003), self-esteem (Mau \& Bikos, 2000), perceived self-efficacy (Fan \& Williams, 2010; McKay, Sumnall, Cole, \& Percy, 2012; van Dinther, Dochy, \& Segers, 2011), social support (Hirschi, Niles, \& Akos, 2011; Kisilu et al., 2012), school commitment (Stewart, Stewart, \& Simons, 2007) and peer-relations (Berzin, 2010). Deleterious influences on aspirations include low-levels of motivation, poor academic performance, aggression, drug abuse and crime (Harris, Duncan, \& Bolsjoly, 2002), lack of social support (Garg et al., 2007; Kisilu et al., 2012) lack of physical activity (Piko \& Keresztes, 2006), dropping out of school (Gutman \& Ackerman, 2008), low-levels of selfefficacy (Bandura et al., 2001), financial constraints and lack of resources (Lekes et al., 2010) can all impede the development of healthy aspirations.

\section{Hope and aspirations}

Aspirations are closely linked to the concept of hope, which denotes the existence of a goal combined with a plan for reaching that goal (Snyder et al., 1991). Contemporary literature on hope suggests that individuals with low levels of hope differ from those with average or high levels, in a number of respects (see Gilman, Dooley, \& Florell, 2006, Snyder et al., 1991). Snyder et al. (1991), for example, found that individuals with low levels of hope struggle more in overcoming obstacles to goal-attainment, in comparison to those who experience higher levels of hope and positive emotions. The relevance of this fact to aspirations becomes clear when one considers the close inter-relationship between goalattainment and aspirations, as indicated by a variety of studies (see Beal \& Crockett, 2010). The close connection between hope and aspirations was further emphasised in a study by Ciarrochi, Heaven, and Davies (2007) where 
adolescents with high levels of hope and aspirations exhibited higher levels of well-being, as well as superior coping and academic skills. These studies underscore the complexity of the construct of aspirations, and hint at both the construct's multidimensional nature, and it's inter-relationship with other psycho-social constructs. Thus, studies are needed on influences of life aspirations among South African adolescents residing in historically disadvantaged communities, as these individuals are particularly confronted with limited access to resources and infrastructural equipment (Watson, McMahon, Foxcroft, \& Els, 2010).

\section{Historical disadvantage and school learner life in South Africa}

South African youth are confronted with shortages of educational and vocational prospects which exacerbate the strain imposed during this time (Fiske \& Ladd, 2004). To a large extent, these shortages are traced back to the sociopolitical history of South Africa, which was characterised by Apartheid, an institutionalised system of racism which resulted in high levels of social inequality and disparities in access to resources. Under Apartheid, young people were subjected to political violence, oppression, and systematic exclusion (Dawes, Tredoux, \& Feinstein, 1989). Despite the abolition of Apartheid in 1994, its legacy persists, manifesting as large income disparities between racial categories, unequal distribution of economic resources (Jarvie, 2014), high levels of unemployment, low levels of education, and poor infrastructure in low-income communities (Hoogeveen \& Özler, 2006). These problems are reflected in the Western Cape, where pervasive inequalities in adolescents' aspirations exist, with more 'Coloured' people (14.5\%) believing that they were unable to accomplish their aspirations in comparison to 'Black' (8.6\%), 'White' (3.2\%) and 'Indian/Asian' (2.3\%) people' (Leoschut, 2009). These discrepancies in adolescents' aspirations reflect the more general social corrosion caused by Apartheid, resulting in frustration, despair and violence, born out of hopelessness and lack of aspirations (Graven, 2014).

Within South Africa, research on this topic is conspicuously lacking. Nonetheless, in accordance with the trends in international literature, a South African study by Shumba and Naong (2012) also highlighted the need to investigate the factors affecting adolescent's aspirations, while Flederman (2009) found that limited infrastructure, high unemployment and extensive poverty that characterises much of South Africa are detrimental to the aspirations of adolescents. Given the findings of preliminary South African research concerning aspirations and its correlates, the need for furthering our understanding of the complexities of adolescents' aspirations and the factors affecting them is particularly urgent. Furthermore, due to South Africa's troubled history of oppression and inequality, the most pressing area for such research endeavours is within impoverished communities where the insidious legacy of Apartheid is most conspicuously apparent.

\section{Goals of the study}

This study sought to investigate the influences on aspirations among adolescents from a low-income community in Cape Town, South Africa.

The following questions guided the study:

- What factors do adolescents identify as influencing their aspirations?

- To what extent do these factors predict adolescents' aspirations?

\section{Method \\ Research design}

The current study adopted a sequential exploratory design (Creswell, 2012), consisting of two phases: qualitative and quantitative. The qualitative phase comprised focus group discussions, while the quantitative phase followed a cross-sectional correlation design. Since literature identified numerous factors that are associated with and affect aspirations, qualitative research methods were used to identify and clarify context-specific factors; while quantitative methods were utilised to conduct further exploration of the identified factors in the quantitative phase.

\section{Participants and setting}

The participants were adolescents residing in a low-income community within the Cape Flats area in Cape Town, South Africa. This community is located approximately $19 \mathrm{~km}$ from the centre of Cape Town, and comprises an estimated population of 19576 (Okecha, 2011). The Cape Flats were originally strategically constructed to house people evicted from other areas during the forced removals of Apartheid. As a consequence of its troubled genesis, these communities are confronted by numerous challenges, including, poor infrastructure, low levels of skills and education, high levels of unemployment, poverty, substance abuse, crime and gangsterism (Savahl, 2010). Male incarceration levels are high, which, coupled with extensive unemployment, places a severe financial and social burden on the women in the community, who are frequently left with the responsibility of raising the family without the support of their partners (Okecha, 2011). A third of the community receives an income through old age pensions, disability and maintenance grants.

The sample for the qualitative phase consisted of 118 adolescents (16-19 years), while the quantitative phase comprised 191 adolescents (14-18 years). Participants were accessed via the secondary school in the community, which formed part of a larger research and intervention programme between the school, community and university at which the principle researchers of the study are based.

\section{Data collection}

In the qualitative phase, data were collected via 16 focus group interviews with seven participants each and one focus group interview with six participants. The focus group interviews comprised six key questions related to adolescents' perceptions of aspirations, barriers and protective factors to achieving aspirations, and their understanding of the most pertinent factors impacting their aspirations (Table 1). 
Table 1: Focus group interview guide

\begin{tabular}{ll}
\hline Question one & $\begin{array}{l}\text { What do you think aspirations are? Give an } \\
\text { example. }\end{array}$ \\
Question two & $\begin{array}{l}\text { Is it possible to have different hopes and } \\
\text { dreams? If yes, why? }\end{array}$ \\
Question three & $\begin{array}{l}\text { Do you think it's important to hope and } \\
\text { dream? Why? }\end{array}$ \\
Question four & Where do you see yourself in five years? \\
Question five & $\begin{array}{l}\text { What things help you achieve your goals/ } \\
\text { hopes/dreams? }\end{array}$ \\
Question six & $\begin{array}{l}\text { What do you think stops you from becoming } \\
\text { what you want to be one day? }\end{array}$ \\
\hline
\end{tabular}

The quantitative phase followed a survey design. The survey instrument was compiled based on the factors identified in the qualitative phase. The instrument consisted of the following standardised scales: The Expectations/ Aspirations measure (Study, Loeber, Stouthamer-Loeber, Van Kammen, \& Farrington, 1991), the New General Self-Efficacy Scale (NGSE) (Chen, Gully, \& Eden, 2001), the Rosenberg Self-Esteem Scale (RSES) (Rosenberg, 1965) and the Multidimensional Scale of Perceived Social Support (MSPSS) (Zimet, Dahlem, Zimet, \& Farley, 1988).

The Expectations/Aspirations measure is a 22-item instrument rated on a 4-point Likert scale (Study et al., 1991). The scale measures the current importance and future expectations of educational and work aspirations, goal orientation, work ethic and values. Responses range from 'very likely' $=1$ to 'not likely at all' $=4$ (Kersteter, 2004). Possible scores on the Expectations/ Aspirations Scale range from 0-88. Kersteter (2004) further reported that the Expectations/Aspirations Scale is a psychometrically sound measure with a Cronbach's alpha of 0.78 and 0.87 for grade 7 and grade 8 learners respectively.

The NGSE consists of 8 items, measuring the belief in one's overall competence. The NGSE scale was scored on a 5-point Likert-type scale from 'strongly disagree' $=1$ to 'strongly agree' $=5$. The initial psychometric evidence for this scale showed internal consistency scores ranging from 0.85 to 0.90 (Chen et al., 2001), and stability coefficient scores ranging from $r=0.62$ to $r=0.65$ (Chen et al., 2001).

The RSES is one of the most widely used measures of global self-esteem (Sinclair et al., 2010). It consists of 10 items, five of which are positively worded, with the other five negatively worded (Sinclair et al., 2010). The RSES was scored on a 4-point Likert scale ranging from 'strongly agree' $=1$ to 'strongly disagree' $=4$. Possible scores on the NGSE range from 0-40. Westaway, Jordaan, and Tsai (2013) reported high reliability coefficients for the scale, with Cronbach's alphas ranging from 0.93 to 0.97 .

The MSPSS measures perceived support in three domains. These domains are: family, friends, and significant others. It contains 12 items, measured on a 7-point Likert scale, ranging from 'very strongly disagree' $=1$ to 'strongly agree' $=7$, with total scores ranging from $0-84$. The measure demonstrates good internal consistency of 0.88 (Duru, 2007), test-retest reliability and factorial validity (Canty-Mitchell \& Zimet, 2000; Chou, 2000).

\section{Credibility and trustworthiness}

Credibility and trustworthiness of the data was achieved by adopting an exploratory sequential design which allowed for multiple data collection techniques. Furthermore, stakeholders were consulted to determine the appropriateness of the instrument for the quantitative data collection. An audit trail was kept of all focus group interview discussions. The audit trails were cross referenced across focus group interviews and with other data sources in order to aid credibility. Finally, member checking was conducted to corroborate the findings with the participants.

\section{Procedure}

Ethical clearance was obtained from the Ethics Committee of the University of the Western Cape, and permission was granted from the Western Cape Education Department. Once the school was contacted, the researchers scheduled a meeting with the school principal and the life skills teacher to discuss an appropriate day, time and venue to conduct the study. Thereafter, the research team met with the participants of the qualitative phase to discuss the nature and scope of the project and the ethics principles of informed consent, confidentiality, anonymity, privacy and the right to withdraw. Participants were required to provide informed consent as well as obtain written informed consent from their parents or legal guardians. Only those who returned signed consent forms participated in the study. The qualitative data collection was conducted in school hours during the administration period and lasted approximately 45 minutes. The quantitative data were collected in the classroom setting and took approximately 20 minutes to complete.

\section{Data analysis}

The data for the qualitative phase were analysed using Braun and Clarke's (2006) theoretical thematic analysis. This involved identifying patterns or themes across the data sets. This was done following Braun and Clarke's (2006) six steps of thematic analysis.

The survey data were analysed applying multiple regression to predict aspirations from self-efficacy, selfesteem and social support. Forced entry multiple regression was used to determine the combined and individual effects of the identified variables on adolescents' aspirations.

\section{Results}

Table 2 provides a summary of the key factors identified by the participants from the thematic analysis of the qualitative data.

The focus group interviews stimulated substantial engagement from the participants and yielded rich data. Table 2 provides a summary of the key factors identified by the participants. The common themes that emerged were further discussed by the researchers and participants in order to elucidate the primary constituents that underlay the data. This process resulted in the identification of three factors that adolescents regarded as the most pertinent to aspirations. These factors were self-efficacy, self-esteem and social support. 
Table 2: Representation of findings in phase 1

\begin{tabular}{llll}
\hline Personal factors & Interpersonal factors & Environmental factors & Financial factors \\
\hline $\begin{array}{l}\text { Attitudes toward the self and } \\
\text { school }\end{array}$ & Family structure & Lack of role models & Family finances \\
$\begin{array}{l}\text { Self-esteem } \\
\text { Self-concept }\end{array}$ & $\begin{array}{l}\text { Family functioning } \\
\text { Peer influence }\end{array}$ & $\begin{array}{l}\text { Substance abuse in community } \\
\text { The effect of substance abuse } \\
\text { on adolescents }\end{array}$ & Family socio-economic statuses \\
$\begin{array}{l}\text { Belief system } \\
\begin{array}{l}\text { Ability to make the right } \\
\text { decision }\end{array}\end{array}$ & $\begin{array}{l}\text { Support from school/teachers } \\
\text { Support from partners }\end{array}$ & \\
$\begin{array}{l}\text { Academic progress/work ethic } \\
\text { Sense of hope }\end{array}$ & $\begin{array}{c}\text { Presence and absence of role } \\
\text { models }\end{array}$ & & \\
\hline
\end{tabular}

For the quantitative phase, data normality tests on the Expectations/Aspirations Scale showed skewness of the residuals at -1.101 with kurtosis at 3.579 . These departures from normality were attended to using bootstrapping (1000 samples). The rest of the assumptions for multiple regression were met.

Table 3 presents the descriptive statistical data on the personal factor variables.

Participants scored high on the Expectations/ Aspirations measure $(M=76.76, \mathrm{SD}=5.64$, range $0-80)$. NGSE range from $0-40(\mathrm{M}=39.16, \mathrm{SD}=5.305$, range $0-40)$, and $\operatorname{RSES}(M=29.82, \mathrm{SD}=5.467$, range $0-40)$, and MSPSS $(\mathrm{M}=63.19, \mathrm{SD}=16.195$, range $0-84)$, indicating that the participants scored relatively high on all these variables.

\section{Personal factor influences}

Forced entry multiple regression was conducted using the Statistical Package for the Social Sciences (version 22). This meant that self-efficacy, self-esteem and social support were entered simultaneously into the regression equation. The results are presented below.

Table 4 presents the ANOVA as a good-fit, indicating that the combined effect of self-efficacy, self-esteem and

Table 3. Sample size, mean and standard deviations of aspirations, self-efficacy, social support and self-esteem

\begin{tabular}{lccc}
\hline & $N$ & Mean & SD \\
\hline Aspirations (EAFP) & 191 & 76.76 & 5.694 \\
Self-efficacy & 191 & 39.16 & 5.305 \\
Self-esteem & 191 & 29.82 & 5.467 \\
Social support & 191 & 63.19 & 16.195 \\
\hline
\end{tabular}

social support significantly predict adolescents' aspirations $(F=17.652, p<0.01)$.

Table 5 shows that self-efficacy is a significantly stronger predictor of adolescents' aspirations than selfesteem and social support $(\beta=0.389, p<0.01)$.

\section{Discussion}

Adolescents in this study held high aspirations and expectations, which is consistent with previous research that found adolescent aspirations to be higher than in adult samples (see Madarasova Geckova, Tavel, van Dijk, Abel, \& Reijneveld, 2010; Mouratidis, Vansteenkiste, Lens, Michou, \& Soenens, 2013; Seekings, 2014). Although previous research shows that educational aspirations and future expectations are lower for adolescents located in disadvantaged communities (Elliott, 2008), the current study found contradictory results. In this sample, adolescents held high aspirations for themselves, despite the low-income environment they reside in.

While substantial information was forthcoming from the participants during the focus group interviews, only the most prominent themes were used to inform the quantitative phase. Although issues around poverty and the low-income environment in which the participants lived were frequently raised, the predominant focus of the discussions centred on more intra-personal factors. One notable exception was the theme of social support, a factor that many of the participants felt was lacking in some aspects of their lives (i.e. family life; school life; community; friends). A lack of social support was specifically identified as a factor that hindered aspirations. Social support was understood to encompass several other

Table 4: Analysis of Variance of self-efficacy, self-esteem and social support

\begin{tabular}{|c|c|c|c|c|c|}
\hline Model & Sum of squares & $\mathrm{df}$ & Mean square & $F$ & $p$ \\
\hline 1 Regression & 1359.547 & 3 & 453.182 & 17.652 & 0.000 \\
\hline Residual & 4800.829 & 187 & 25.673 & & \\
\hline Total & 6160.376 & 190 & & & \\
\hline
\end{tabular}

*Regression is significant at the 0.01 level (2-tailed)

Table 5: Bootstrap for coefficients

\begin{tabular}{|c|c|c|c|c|c|c|}
\hline \multirow{2}{*}{ Model } & \multirow{2}{*}{$B$} & \multirow{2}{*}{ Bias } & \multirow{2}{*}{ SE } & \multirow{2}{*}{$p$} & \multicolumn{2}{|c|}{$95 \%$ confidence interval } \\
\hline & & & & & Lower & Upper \\
\hline 1 (Constant) & 58.696 & -0.532 & 3.701 & 0.001 & 49.832 & 64.887 \\
\hline SelfEffTot & 0.389 & 0.016 & 0.121 & 0.004 & 0.185 & 0.664 \\
\hline SelfEstTot & 0.119 & -0.003 & 0.071 & 0.095 & -0.032 & 0.254 \\
\hline SocSupportTot & 0.033 & 0.002 & 0.025 & 0.186 & -0.013 & 0.085 \\
\hline
\end{tabular}

Note. SelfEffTot $=80$, SelfEstTot $=40$, SocSupportTot $=84 *$ Regression is significant at the 0.01 level (2-tailed) 
factors (e.g. support from one's school, teachers, and partners were all raised separately, but are more succinctly expressed by the broader concept of social support). Another interesting finding was that the participants reported feelings of alienation from the community and peers should they express overly positive goals and aspirations.

The two intra-personal factors that emerged from the focus group interviews were self-esteem and self-efficacy. The importance of self-esteem and self-efficacy on aspirations has been highlighted in previous research (see Carroll, 2009; Mau \& Bikos, 2000) and the prominence of these two factors in the discussion groups reflects this fact. However, the participants identified a wide range of other factors that they considered relevant to aspirations, such as one's belief systems and sense of hope regarding the future. The intra-personal factors identified were mostly related to increased aspirations and linked to individual chances of success. Self-efficacy and self-esteem, however, were raised more frequently than the other interpersonal factors and the participants indicated that the other factors were less important.

A core finding of this study is that the combined influence of self-efficacy, self-esteem and social support significantly predict adolescents' aspirations. This finding is not surprising, as a substantial body of literature found associations between self-efficacy and aspirations (Kerpelman, Eryigit, \& Stephens, 2008; van Dinther et al., 2011), social support and aspirations (Madarasova Geckova et al., 2010), and self-esteem and aspirations (Carranza, You, Chhuon, \& Hudley, 2009). However, the current study is one of the first to show the predictive utility of combining domains of person-related (selfefficacy and self-esteem) and contextual (social support) variables in influencing adolescents' aspirations in a disadvantaged community in Cape Town.

Self-efficacy proved to be a significantly stronger predictor of aspirations than self-esteem and social support. This finding supports the contention in existing literature that the stronger the perceived self-efficacy, the higher the aspirations (Bandura \& Locke, 2003; Boxer, Goldstein, DeLorenzo, Savoy, \& Mercado, 2011; McKay et al., 2012; Sawitri, Creed, \& Zimmer-Gembeck, 2014). The importance of self-efficacy is further underscored by the information that emerged in the discussion groups. For example, adolescents relied more on their own abilities than gaining support from family, friends and community. In fact, contrary to existing literature, evidence from the focus group discussions indicated that adolescents perceived family, friends and community members as possible barriers to aspirations. Similar findings emerged in qualitative research conducted by Isaacs and Savahl (2014) and Savahl (2010) in impoverished communities in Cape Town. Adolescent and youth participants in these studies reported being ostracised for aspiring or achieving. Aspirations are then perceived as a negative endeavour. It follows then that adolescents and young people tend to believe that opportunities for success are located in the autonomous self and that external support will not be as forthcoming.

\section{Implications for life skills support within disadvantaged communities}

The importance of aspirations in many domains of life is well-researched (see Akos, Lambie, Milsom, \& Gilbert, 2007; Bandura et al., 2001; Hill et al., 2004). However, one of the contributions of this study was to underscore the relevance of self-efficacy and its relation to adolescents' aspirations. Caroll, Gordon, Houghton, Unsworth, and Wood (2012) stated that academic self-efficacy is strongly related to aspirations, and fostering self-efficacy among young people could facilitate positive self-beliefs and involvement in academic and school-related activities. Considering the findings from the current study, life skills counsellors may wish to consider incorporating attempts at improving self-efficacy in life skills programs.

\section{Limitations of the study}

A key limitation of this study was that the data were collected from only one community, thus limiting the generalisability of the study findings. Future studies should utilise representative samples when exploring the role of self-efficacy on aspirations in impoverished communities. Another limitation relates to the nature and scope of the qualitative phase which was used to identify the key factors influencing aspirations. Specifically, data from the focus group interviews were not fully explored, and as a result the qualitative analysis lacked depth. Future research on adolescents' aspirations should involve conducting more in-depth qualitative studies using advanced analysis techniques. The quantitative phase of the study did not display significance for self-esteem and social support, however, the prominence of these two issues in the qualitative phase of the study is worthy of consideration. Non-significant results may be explained by a variety of factors, and the importance ascribed to social support and self-esteem in the focus group interviews warrants attention and may be of use in the field of life skills counselling, especially given the existing research that highlights the relevance of these constructs in personal well-being (Sheldon, 2002).

\section{Conclusion}

The current study was guided by two research questions pertaining to adolescents' perceptions of factors that influenced their aspirations and the extent to which these factors significantly predicted aspirations. It was found that adolescents were not only familiar with the notion of aspirations, but they were also able to identify the factors that affected their aspirations both positively and negatively.

The study further found that self-efficacy, social support, and self-esteem were considered by adolescents to be the most important factors impacting on their aspirations. Finally the study revealed that while the combined influence of these factors significantly predicted aspirations, individually only self-efficacy was a significant predictor.

\section{Notes}

1. The terms 'Coloured', 'Black', and 'Indian', were employed as racial categories within the Apartheid era to reinforce a segregated society, and refer to those who were not afforded 
the same benefits 'Whites' in this era. These terms are used here solely for descriptive purposes, and does not imply acknowledgement of these terms by the authors.

\section{References}

Akos, P., Lambie, G. W., Milsom, A., \& Gilbert, K. (2007). Early adolescents' aspirations and academic tracking: An exploratory investigation. Professional School Counseling, 11(1), 57-64. http://dx.doi.org/10.5330/PSC.n.2010-11.57

Bandura, A., Barbaranelli, C., Caprara, G. V., \& Pastorelli, C. (2001). Self-efficacy beliefs as shapers of children's aspirations and career trajectories. Child Development, 72(1), 187-206. http://dx.doi.org/10.1111/1467-8624.00273

Bandura, A. (1993). Perceived self-efficacy in cognitive development and functioning. Educational Psychologist, 28(2), 117-148. http://dx.doi.org/10.1207/ s15326985ep2802 3

Bandura, A., \& Locke, E. A. (2003). Negative self-efficacy and goal effects revisited. The Journal of Applied Psychology, 88(1), 87-99. http://dx.doi.org/10.1037/0021-9010.88.1.87

Beal, S. J., \& Crockett, L. J. (2010). Adolescents' occupational and educational aspirations and expectations: Links to high school activities and adult educational attainment. Developmental Psychology, 46(1), 258-265. http://dx.doi. org/10.1037/a0017416

Berzin, S. C. (2010). Educational aspirations among low-income youths: Examining multiple conceptual models. Children \& Schools, 32(2), 112-124. http://dx.doi.org/10.1093/ $\operatorname{cs} / 32.2 .112$

Boxer, P., Goldstein, S. E., DeLorenzo, T., Savoy, S., \& Mercado, I. (2011). Educational aspiration-expectation discrepancies: Relation to socioeconomic and academic risk-related factors. Journal of Adolescence, 34(4), 609-617. http://dx.doi. org/10.1016/j.adolescence.2010.10.002

Braun, V., \& Clarke, V. (2006). Using thematic analysis in psychology. Qualitative Research in Psychology, 3(2), 77-101. http://dx.doi.org/10.1191/1478088706qp063oa

Canty-Mitchell, J., \& Zimet, G. D. (2000). Psychometric properties of the multidimensional perceived scale of perceived social support in urban adolescents. American Journal of Community Psychology, 28(3), 391-400. http:// dx.doi.org/10.1023/A:1005109522457

Carranza, F. D., You, S., Chhuon, V., \& Hudley, C. (2009). Mexican American adolescents' academic achievement and aspirations: The role of perceived parental educational involvement, acculturation, and self-esteem. Adolescence, 44(174), 313

Carroll, A., Houghton, S., Wood, R., Unsworth, K., Hattie, J., Gordon, L., \& Bower, J. (2009). Self-efficacy and academic achievement in Australian high school students: The mediating effects of academic aspirations and delinquency. Journal of Adolescence, 32(4), 797-817. http://dx.doi. org/10.1016/j.adolescence.2008.10.009

Chen, G., Gully, S. M., \& Eden, D. (2001). Validation of a new general self-efficacy scale. Organizational Research Methods, 4(1), 62-83. http://dx.doi.org/10.1177/109442810141004

Chou, K. L. (2000). Assessing Chinese adolescents' social support: The multidimensional scale of perceived social support. Personality and Individual Differences, 28(2), 299-307. http://dx.doi.org/10.1016/S0191-8869(99)00098-7

Ciarrochi, J., Heaven, P. C., \& Davies, F. (2007). The impact of hope, self-esteem, and attributional style on adolescents' school grades and emotional well-being: A longitudinal study. Journal of Research in Personality, 41(6), 1161-1178. http://dx.doi.org/10.1016/j.jrp.2007.02.001

Creswell, J. W. (2012). Qualitative inquiry and research design: Choosing among five approaches. New York: Sage.

Dawes, A., Tredoux, C., \& Feinstein, A. (1989). Political violence in South Africa: Some effects on children of the violent destruction of their community. International Journal of Mental Health 32: 283-289,
Duru, E. (2007). Re-examination of the psychometric characteristics of the multidimensional scale of perceived social support among Turkish university students. Social Behavior and Personality, 35(4), 443-452. http://dx.doi. org/10.2224/sbp.2007.35.4.443

Elliott, W. (2008). Closing the gap between aspirations and expectations among disadvantaged students: The potential of students' savings for future schooling and household wealth. Ann Arbor, MI: ProQuest.

Fan, W., \& Williams, C. M. (2010). The effects of parental involvement on students' academic self-efficacy, engagement and intrinsic motivation. International Journal of Experimental Educational Psychology, 30(1), 53-74.

Fiske, E. B., \& Ladd, H. F. (2004). Elusive equity: Education reform in post-apartheid South Africa. Washington, DC: Brookings Institution Press.

Flederman, P. (2009). Navigational tools for learners, really? What is available, what are the challenges and what should be done? An environmental scan of the careers guidance field in South Africa. In South African Qualifications Authority, Career guidance challenges and opportunities. Waterkloof: South African Qualifications Authority.

Flowers, L. A., Milner, H. R., \& Moore, J. L. (2003). Effects of locus control on African American high school seniors' educational aspirations: Implications for preservice and inservice high school teachers and counselors. High School Journal, 87(1), 39-50. http://dx.doi.org/10.1353/ hsj.2003.0014

Garg, R., Melanson, S., \& Levin, E. (2007). Educational aspirations of male and female adolescents from singleparent and two biological parent families: A comparison of influential factors. Journal of Youth and Adolescence, 36(8), 1010-1023. http://dx.doi.org/10.1007/s10964-006-9137-3

Gilman, R., Dooley, J., \& Florell, D. (2006). Relative levels of hope and their relationship with academic and psychological indicators among adolescents. Journal of Social and Clinical Psychology, 25(2), 166-178. http://dx.doi.org/10.1521/ jscp.2006.25.2.166

Gottfredson, L. S. (1981). Circumscription and compromise: A developmental theory of occupational aspirations. Journal of Counseling Psychology, 28(6), 545-579. http://dx.doi. org/10.1037/0022-0167.28.6.545

Gottfredson, L. S. (2005). Using Gottfredson's theory of circumscription and compromise in career guidance and counseling. In S. D. Brown \& R. W. Lent (Eds.), Career development and counseling: Putting theory and research to work (pp. 71-100). New York: Wiley.

Graven, M. H. (2014). Poverty, inequality and mathematics performance: the case of South Africa's post-apartheid context. ZDM 46(7): 1039-1049

Gutman, L.M., \& Akerman, R. (2008). Determinants of aspirations. London: Centre for Research on the Wider Benefits of Learning, Institute of Education, University of London.

Harris, K. M., Duncan, G. J., \& Boisjoly, J. (2002). Evaluating the role of "nothing to lose" attitudes on risky behaviour in adolescence. Social Forces, 80(3), 1005-1039. http://dx.doi. org/10.1353/sof.2002.0008

Hellenga, K., Aber, M. S., \& Rhodes, J. E. (2002). African American adolescent mothers' vocational aspirationexpectation gap: Individual, social and environmental influences. Psychology of Women Quarterly, 26(3), 200-212. http://dx.doi.org/10.1111/1471-6402.00059

Hill, N. E., Castellino, D. R., Lansford, J. E., Nowlin, P., Dodge, K. A., Bates, J. E., \& Pettit, G. S. (2004). Parent academic involvement as related to school behavior, achievement, and aspirations: Demographic variations across adolescence. Child Development, 75(5), 1491-1509. http://dx.doi. org/10.1111/j.1467-8624.2004.00753.x 
Hirschi, A., Niles, S. G., \& Akos, P. (2011). Engagement in adolescent career preparation: Social support, personality and the development of choice decidedness and congruence. Journal of Adolescence, 34(1), 173-182. http://dx.doi. org/10.1016/j.adolescence.2009.12.009

Hoogeveen, J. G., \& Özler, B. (2006). Poverty and inequality in post-apartheid South Africa: 1995-2000. Poverty and Policy in Post-apartheid South Africa, 59-94.

Isaacs, S. A., \& Savahl, S. (2014). A qualitative inquiry investigating adolescents' sense of hope within a context of violence in a disadvantaged community in Cape Town. Journal of Youth Studies, 17(2), 269-278. http://dx.doi. org/10.1080/13676261.2013.815703

Jarvie, G. (2014). Class race sport. London: Routledge.

Kerpelman, J. L., Eryigit, S., \& Stephens, C. J. (2008). African American adolescents' future education orientation: Associations with self-efficacy, ethnic identity and perceived parental support. Journal of Youth and Adolescence, 37(8), 997-1008. http://dx.doi.org/10.1007/s10964-007-9201-7

Kersteter, S. (2004). Expectations/Aspirations (Fast Track Project Technical Report). Available online: http://www. fasttrackproject.org (Retrieved 26 April 2014).

Kisilu, J., Kimani, E., \& Kombo, D. (2012). Factors influencing aspirations among girls in secondary schools in Nairobi region - Kenya. Prime Research on Education, 2(4), 244-251.

Lekes, N., Gingras, I., Philippe, F. L., Koestner, R., \& Fang, J. (2010). Parental autonomy-support, intrinsic life goals, and well-being among adolescents in China and North America. Journal of Youth and Adolescence, 39(8), 858-869. http:// dx.doi.org/10.1007/s10964-009-9451-7

Leoschut, L. (2009). Running Nowhere Fast: Results of the 2008 National Youth Lifestyle Study. Cape Town: Centre for Justice and Crime Prevention.

Madarasova Geckova, A., Tavel, P., van Dijk, J. P., Abel, T., \& Reijneveld, S. A. (2010). Factors associated with educational aspirations among adolescents: Cues to counteract socioeconomic differences? BMC Public Health, 10(1), 154-165. http://dx.doi.org/10.1186/1471-2458-10-154

Mau, W.-C., \& Bikos, L. H. (2000). Educational and vocational aspirations of minority and female students: A longitudinal study. Journal of Counseling and Development, 78(2), 186-194. http://dx.doi.org/10.1002/j.1556-6676.2000. tb02577.x

McKay, M., Sumnall, H. R., Cole, J. C., \& Percy, A. (2012). Self-esteem and self-efficacy: Associations with alcohol consumption in a sample of adolescents in Northern Ireland. Drugs Education Prevention \& Policy, 19(1), 72-80. http:// dx.doi.org/10.3109/09687637.2011.579585

Mouratidis, A., Vansteenkiste, M., Lens, W., Michou, A., \& Soenens, B. (2013). Within-person configurations and temporal relations of personal and perceived parent-promoted aspirations to school correlates among adolescents. Journal of Educational Psychology, 105(3), 895-910. http://dx.doi. org/10.1037/a0032838

Okecha, K. (2011). Regime politics and service delivery in the Cape Town unicity council area. Urban Forum, 22, 95-110.

Piko, B. F., \& Keresztes, N. (2006). Physical activity, psychosocial health and life goals among youth. Journal of Community Health, 31(2), 136-145. http://dx.doi. org/10.1007/s10900-005-9004-2

Rosenberg, M. (1965). Society and the adolescent child. Princeton: Princeton University Press.

Ryan, R. M., \& Deci, E. L. (2000). Self-determination theory and the facilitation of intrinsic motivation, social development, and well-being. The American Psychologist, 55(1), 68-78. http://dx.doi.org/10.1037/0003-066X.55.1.68
Savahl, S. (2010). Ideological constructions of childhood. Unpublished doctoral dissertation. University of the Western Cape, Bellville.

Sawitri, D. R., Creed, P. A., \& Zimmer-Gembeck, M. J. (2014) Longitudinal relations of parental influences and adolescent career aspirations and actions in a collectivist society. Journal of Research on Adolescence, n/a. http://dx.doi. org/10.1111/jora.12145

Seekings, J. (2014). The social and political implications of demographic change in post-apartheid South Africa. The Annals of the American Academy of Political and Social Science, 652(1), 70-86. http://dx.doi. org/10.1177/0002716213508265

Sewell, W. H., Haller, A. O., \& Ohlendorf, G. W. (1970). The educational and early occupational status attainment process: Replication and revision. American Sociological Review, 35(6), 1014-1027. http://dx.doi.org/10.2307/2093379

Sheldon, K. M. (2002). The self-concordance model of healthy goal-striving: When personal goals correctly represent the person. Handbook of Self-determination Research, 65-86.

Shumba, A., \& Naong, S. (2012). Factors influencing students' career choice and aspirations in South Africa. Journal of Social Science, 33(2), 169-178.

Sinclair, S. J., Blais, M. A., Gansler, D. A., Sandberg, E., Bistis, K., \& LoCicero, A. (2010). Psychometric properties of the Rosenberg Self-Esteem Scale: Overall and across demographic groups living within the United States. Evaluation \& the Health Professions, 33(1), 56-80. http:// dx.doi.org/10.1177/0163278709356187

Snyder, C. R., Harris, C., Anderson, J. R., Holleran, S. A., Irving, L. M., Sigmon, S. T., . . . Harney, P. (1991). The will and the ways: Development and validation of an individualdifferences measure of hope. Journal of Personality and Social Psychology, 60(4), 570-585. http://dx.doi. org/10.1037/0022-3514.60.4.570

Stewart, E. B., Stewart, E. A., \& Simons, B. K. (2007). The effect of neighbourhood context on the college aspirations of African American adolescents. American Educational Research Journal, 44(4), 896-919. http://dx.doi. org/10.3102/0002831207308637

Study, P. Y., Loeber, R., Stouthamer-Loeber, M., Kammen, W. V., \& Farrington, D. P (1991). Initiation, escalation and desistance in juvenile offending and their correlates. Journal of Criminal Law \& Criminology, 82(1), 36. http://dx.doi. org/10.2307/1143789

Super, D. E. (1980). A life-span, life-space approach to career development. Journal of Vocational Behavior, 16(3), 282-298. http://dx.doi.org/10.1016/0001-8791(80)90056-1

Van Dinther, M., Dochy, F., \& Segers, M. (2011). Factors affecting students' self-efficacy in higher education. Journal of Educational Research Reviews, 6(2), 95-108. http:// dx.doi.org/10.1016/j.edurev.2010.10.003

Watson, M., McMahon, M., Foxcroft, C., \& Els, C. (2010) Occupational aspirations of low socioeconomic black South African children. Journal of Career Development, 37(4), 4717-4737. http://dx.doi.org/10.1177/0894845309359351

Westaway, M. S., Jordaan, E. R., \& Tsai, J. (2013). Investigating the psychometric properties of the Rosenberg Self-Esteem Scale for South African residents of Greater Pretoria. Evaluation \& the Health Professions, 00(0), 1-19.

Zimet, G. D., Dahlem, N. W., Zimet, S. G., \& Farley, G. K. (1988). The multidimensional scale of perceived social support. Journal of Personality Assessment, 52(1), 30-41. http://dx.doi.org/10.1207/s15327752jpa5201 